\title{
A scientific note on the occurrence of Euglossini bees in the Caatinga, a Brazilian tropical dry forest*
}

\author{
Ariadna Valentina LOPES ${ }^{\text {a** }}$, Isabel Cristina MACHADO ${ }^{\mathrm{a}}$, Antônio Venceslau de AGUIAR ${ }^{\text {a*** }}$, José Manuel \\ Macário REBÊLo ${ }^{\mathrm{b}}$ \\ ${ }^{a}$ Departamento de Botânica, Universidade Federal de Pernambuco, Rua Prof. Nelson Chaves s/n, Recife, PE, 50372-970, \\ Brazil \\ ${ }^{\mathrm{b}}$ Departamento de Biologia, Universidade Federal do Maranhão, Av. dos Portugueses s/n, Campus do Bacanga, São \\ Luís, MA, 65040-080, Brazil
}

Received 20 June 2006 - Revised 20 June 2007 - Accepted 21 June 2007

Euglossini / orchid bees / odour baits / Caatinga / northeastern Brazil

Euglossini bees (Apidae) are an exclusively Neotropical monophyletic group of five genera (Aglae, Eufriesea, Euglossa, Eulaema, and Exaerete) with 190 species, (Rebêlo, 2001; Ramírez, 2005). In Brazil, the second most diverse country in Euglossini species (Ramírez et al., 2002), 80 species are referred for the Amazon, 57 for the Atlantic forest, and 23 for the Cerrado (Rebêlo, 2001). Despite this high richness, new species continue to be described (Ramírez, 2005) and known species are still being recorded from new locations (Nemésio and Silveira, 2004).

The Caatinga, a semi-arid ecosystem unique from Brazil, is a deciduous forest with scrub vegetation. It occurs in areas of low and highly seasonal rainfall $(500-700 \mathrm{~mm} / \mathrm{year})$, and covers $800000 \mathrm{~km}^{2}$ of Brazil's territory (ca. 8.6\%) in the northeastern region (Leal et al., 2003). It was estimated that more than $40 \%$ of its plant species relies on bees for pollination (Machado and Lopes, 2004). However, the Caatinga apifauna is still poorly known (Zanella, 2000; Zanella and Martins, 2003).

The aim of this paper is to review and report new records of Euglossini bees for the Caatinga region. We inventoried five sites located in the states of Pernambuco (PE) and Ceará (CE), Brazil (see material online) by attracting Euglossini males using odour

Corresponding author: A.V. Lopes,

avflopes@ufpe.br

* Manuscript editor: Walter S. Sheppard

** Current Address: Department of Wildlife Ecology and Conservation, University of Florida, PO Box 110430, Gainesville, FL 32611-0430, Florida, USA. baits (skatole, methyl salicilate, $\beta$-ionone, vanillin, benzyl acetate, and eucalyptol), as established by Dodson et al. (1969) and broadly applied by numerous authors. Individuals were attracted from 8:00 to 12:00 h, according to usual protocols for Euglossini male collection (e.g. Pearson and Dressler, 1985; Wittmann et al., 2000; Rebêlo 2001; Pemberton and Wheeler, 2006, and references therein). The filter papers used as baits were saturated each $30 \mathrm{~min}$. with the fragrances to ensure efficiency. Specimens preparation followed usual protocols in entomology and were deposited in the collection of the Laboratory of Floral and Reproductive Biology at the Universidade Federal de Pernambuco, Brazil. For $E$ ulaema individuals, easily identified in the field, the first specimen captured was kept as testimonial, and the following were marked with non-toxic ink, then released.

In total, 173 individuals from three species were collected: Eulaema nigrita (Lepeletier, 1841), Euglossa cordata (Linnaeus), 1758, and Eg. securigera Dressler, 1982 (Tab. I). In a previous revision on bees of the Caatinga only three species of Euglossini were referred to this entire ecosystem: El. nigrita, Eg. securigera, Eufriesea nordestina Moure, 1999 (Zanella, 2000). Zanella (2000), during a "year-round survey", collected only one species of Euglossini (El. nigrita). Subsequently, Martins et al. (2003) referred to another species, Eg. melanotricha Moure, 1967, in a Caatinga area. By recording Eg. cordata in the present study, five species are now known for the Caatinga. This species was also found to occur in Altitudinal forests ("Brejos de Altitude") surrounded by Caatinga in Pernambuco state, and was seen to leave 
Table I. Euglossini species attracted to odour baits at four Caatinga sites (1. Mombaça-CE; 2. Missão VelhaCE; 3. Lagoa Grande-PE; 4. Crato-Arajara-CE), and one site of Dense Montane forest (5. Floresta Nacional do Araripe-CE) in the States of Pernambuco (PE) and Ceará (CE), northeastern Brazil.

\begin{tabular}{lccccccc}
\hline & \multicolumn{4}{c}{ Sites (number of individuals) } & \multicolumn{3}{c}{ Total } \\
\cline { 2 - 8 } & 1 & 2 & 3 & 4 & 5 & $\mathrm{~N}$ & $\%$ \\
\hline Eulaema nigrita & 36 & 8 & - & 27 & 63 & 134 & 77.4 \\
Euglossa cordata & 5 & 6 & 3 & 9 & 14 & 37 & 21.4 \\
Euglossa securigera & 2 & - & - & - & - & 2 & 1.2 \\
\hline Total abundance & 43 & 14 & 3 & 36 & 77 & 173 & 100 \\
\hline
\end{tabular}

these forests to nearby agroforests (Wittmann et al., 2000).

The low richness of these bees in the Caatinga was expected since the distribution of this tribe is strongly associated with humidity (Rebêlo, 2001). Even in Montane forests, surrounded by dry forests, the richness of Euglossini was low compared with values for the Atlantic and Amazon ones (Rebêlo, 2001). Due to its rarity, it is suggested that interactions between plants and Euglossini bees in the Caatinga focus on the dependence of each mutualist.

Our findings are relevant because they (1) increase the number of Euglossini bees registered for the ecosystem, (2) compile and update "orchid bee" geographic distribution for the ecosystem, providing information for the comprehension of the biogeographic relations between the Caatinga and other ecosystems (see Prado, 2003; Zanella and Martins, 2003), and (3) make available information for conservation planning and management, including agroforestry initiatives.

\section{ACKNOWLEDGEMENTS}

We thank the CNPq (A.V. Lopes and I.C. Machado) and the CAPES (A.V. Aguiar) for essential financial support and Dr. Fábio Olmos for inviting us for inventorying the areas.

Note scientifique sur la présence des abeilles Euglossini dans le Caatinga, forêt sèche tropicale du Brésil.

Eine wissenschaftliche Notiz über das Vorkommen von Euglossinen Bienen in der Caatinga, einem tropischen Trockenwald in Brasilien.

\section{REFERENCES}

Dodson C.H., Dressler R.L., Hills H.G., Adams R.M, Williams N.H. (1969) Biologically active compounds in orchid fragrances, Science 164, 1243-1249.
Leal I.R., Tabarelli M., Silva J.M.C. (2003) Ecologia e conservação da Caatinga, Editora Universitária -UFPE, Recife.

Machado I.C., Lopes A.V. (2004) Floral traits and pollination systems in the Caatinga, a brazilian tropical dry forest, Ann. Bot. 94, 1-12.

Martins C.F., Moura A.C.A., Barbosa M.R.V. (2003) Bee plants and relative abundance of corbiculate Apidae species in a Brazilian Caatinga Area, Rev. Nord. Biol. $17,63-74$.

Nemésio A., Silveira F.A. (2004) Biogeographic Notes on Rare Species of Euglossina (Hymenoptera: Apidae: Apini) Occurring in the Brazilian Atlantic Rain Forest, Neotrop. Entomol. 33, 117-120.

Pearson D.L., Dressler R.L. (1985) Two year study of male orchid bees (Hymenoptera: Apidae: Euglossini) attraction to chemical baits in a lowland South-eastern Peru, J. Trop. Ecol. 1, 37-54.

Pemberton R.W., Wheeler G.S. (2006) Orchid bees don't need orchids: evidence from the naturalization of an orchid bee in Florida, Ecology 87, 1995-2001.

Prado D. (2003) As Caatingas da América do Sul, in: Leal I.R., Tabarelli M., Silva J.M.C. (Eds.), Ecologia e conservação da Caatinga, Editora Universitária-UFPE, Recife, pp. 3-73.

Ramírez S. (2005) Euglossa paisa, a new species of orchid bee from the Colombian Andes (Hymenoptera: Apidae), Zootaxa 1065, 51-60.

Ramírez S., Dressler R.L, Ospina M. (2002) Abejas euglosinas (Hymenoptera: Apidae) de la Región Neotropical: listado de especies con notas sobre su biología, Biota Colomb. 3, 7-118.

Rebêlo J.M.M. (2001) História natural das euglossíneas - as abelhas das orquídeas, Lithograf Editora, São Luís.

Wittmann D., Hamm A., Machado I.C., Schiffler D., Schlindwein C. (2000) Artenvielfalt von Euglossinen in einem Regenwald-Fragment und angrenzenden landwirtschaftlichen Nutzflächen in Pernambuco, Brasilien, Beitr. Hymenopterologen- Tagung in Stuttgart 2000, pp. 67-70.

Zanella F.C.V. (2000) The bees of the Caatinga (Hymenoptera, Apoidea, Apiformes): a species list and comparative notes regarding their distribution, Apidologie 31, 579592.

Zanella F.C.V., Martins C.F. (2003) Abelhas da Caatinga: biogeografia, ecologia e conservação, in: Leal I.R., Tabarelli M., Silva J.M.C. (Eds.), Ecologia e conservação da Caatinga, Editora Universitária -UFPE, Recife, pp. 75134. 


\section{Online Materials}


Table. Sites inventoried in the States of Pernambuco (PE) and Ceará (CE), northeastern Brazil.

\begin{tabular}{|c|c|c|c|}
\hline Location & Coordinate & Altitude & Site description \\
\hline 1. Mombaça (CE) & $\begin{array}{l}05^{\circ} 39^{\prime} 53^{\prime \prime} \mathrm{S} \\
39^{\circ} 37^{\prime} 00^{\prime \prime} \mathrm{W}\end{array}$ & $278 \mathrm{~m}$ & $\begin{array}{l}\text { Caatinga area with dense } \\
\text { shrubs and trees, surrounded } \\
\text { by lakes/basins, marked by } \\
\text { the occurrence of Auxemma } \\
\text { oncocalyx (Boraginaceae), a } \\
\text { tall tree endemic of the CE } \\
\text { and Rio Grande do Norte } \\
\text { States }\end{array}$ \\
\hline 2. Missão Velha (CE) & $\begin{array}{l}07^{\circ} 18^{\prime} 09^{\prime \prime} \mathrm{S} \\
39^{\circ} 01^{\prime} 13^{\prime \prime} \mathrm{W}\end{array}$ & $450 \mathrm{~m}$ & $\begin{array}{l}\text { Shrubby Caatinga. Evidence } \\
\text { of intense antropic activity } \\
\text { (e.g. logging, burning, cattle } \\
\text { trails) }\end{array}$ \\
\hline 3. Lagoa Grande (PE) & $\begin{array}{l}08^{\circ} 49^{\prime} 58^{\prime \prime} \mathrm{S} \\
40^{\circ} 10^{\prime} 33^{\prime \prime} \mathrm{W}\end{array}$ & $450 \mathrm{~m}$ & $\begin{array}{l}\text { Shrubby Caatinga. Numerous } \\
\text { tall individuals of Schinopsis } \\
\text { brasiliensis (Anacardiaceae), } \\
\text { and Anadenanthera macro- } \\
\text { carpa (Leguminosae); Jat- } \\
\text { ropha spp. (Euphorbiaceae) } \\
\text { was also highly present }\end{array}$ \\
\hline 4. Crato-Arajara (CE) & $\begin{array}{l}07^{\circ} 15^{\prime} 48^{\prime \prime} \mathrm{S} \\
39^{\circ} 23^{\prime} 38^{\prime \prime} \mathrm{W}\end{array}$ & $500 \mathrm{~m}$ & $\begin{array}{l}\text { Caatinga area marked by } \\
\text { the presence of many tree } \\
\text { species, and surrounded by } \\
\text { agroforests }\end{array}$ \\
\hline $\begin{array}{l}\text { 5. Floresta Nacional } \\
\text { do Araripe, Crato (CE) }\end{array}$ & $\begin{array}{l}07^{\circ} 18^{\prime} 31^{\prime \prime} \mathrm{S} \\
39^{\circ} 27^{\prime} 12^{\prime \prime} \mathrm{W}\end{array}$ & $923 \mathrm{~m}$ & $\begin{array}{l}\text { Dense Montane forest area } \\
\text { surrounded by Caatinga }\end{array}$ \\
\hline
\end{tabular}

